\title{
Václav Havel: niepolityczny polityk
}

\begin{abstract}
Bankowicz Marek, Václav Havel: niepolityczny polityk (Václav Havel: Non-political Politician). „Poznańskie Studia Slawistyczne” 6. Poznań 2014. Publishing House Science and Innovate, pp. 33-48. ISBN 978-83-63795-51-1. ISSN 2084-3011.
\end{abstract}

The article presents the political and intellectual silhouette of Václav Havel (1936-2011) - the last president of Czechoslovakia and the first one of the Czech Republic. Havel, the next to the Pole Lech Wałęsa, is the world renown symbol of the political turning point of 1989 that ended the world communist system. Before 1989, during the communist age, Havel was a dramatist, essayist and leader of Czechoslovak anticommunist and democratic dissident movement. He was strongly persecuted by the ruling communists, and while living under a permanent supervision of the security services and he was many times arrested. In 1989 Havel became a president of democratic Czechoslovakia and after dissolving of this state, in 1993, he was elected as a the first president of the new Czech Republic, holding the office by 10 following years. Havel was very untypical politician and president. He has played rather the role of an intellectual for whom politics is a matter of changing reality not by political decisions, but as a result of impact the on world by ideas and views. To follow Thomas Garrigue Masaryk example, the founder and first head of Czechoslovak state, clearly admired by Havel, he has tried to conduct of non-political politics. In this model politics becomes a practical applying of ethics and most important within it is not a power or state procedures and mechanisms, but men's good and faithfulness to the truth. Václav Havel went down in the history as one of the greatest political figures of the second half of the last century.

Keywords: politics; non-political politics; dramatist; communism; dissident movement; democratic opposition; president; presidency; Czechoslovakia; Czech Republic

Václav Havel (1936-2011) należy do grona tych nielicznych ludzi, o których można powiedzieć, że w drugiej połowie XX wieku uratowali honor Europy Środkowej, gdyż w imię godności człowieka i prawa do życia w prawdzie mieli odwagę aktywnie sprzeciwić się totalitarnej komunistycznej dyktaturze i podtrzymywali marzenie o wolności. Obok Polaka, Lecha Wałęsy, Václav Havel jest też symbolem epokowego politycznego przełomu z roku 1989, który położył kres światowemu systemowi komunistycznemu i przeszedł do historii jako Jesień Narodów. 
Będąc prezydentem najpierw Czechosłowacji, a potem Republiki Czeskiej, Václav Havel stał się postacią powszechnie szanowaną i zaliczony został do grona największych autorytetów współczesnego świata nie tylko politycznych, ale także moralnych. Jego głos, jakże często osadzony w szczerym humanizmie i głęboko motywowany etycznie, ważył bardzo wiele w polityce międzynarodowej. Wysoki prestiż, jakim cieszył się prezydent, wpłynął też w oczywisty sposób na dobrą opinię państwa - Republiki Czeskiej. Można by powiedzieć, że przez lata Havel stanowił najlepszy czeski produkt eksportowy.

W sensie politycznym Havel reprezentował się jako ktoś zupełnie nieszablonowy, ktoś, kto wymykał się wszelkim tradycyjnym podziałom i typologiom. Trudno go bowiem uznać za liberała, konserwatystę czy socjalistę. Nie był przy tym czeskim nacjonalistą, ale nie należał też do grona europejskich kosmopolitów. Kim więc był? Intelektualistą zaplątanym w świat polityki, stawiającym sobie za cel zmianę rzeczywistości poprzez siłę swych idei i przekonań, w miejsce mocy politycznych decyzji. Stał się zatem politykiem zgoła niepolitycznym, a po osiągnięciu prezydentury sprawował najwyższy w państwie urząd w sposób zupełnie nieprezydencki. Nieprzypadkowo zatem najpełniej identyfikował się z wyjątkową formułą niepolitycznej polityki, którą z uporem głosił i upowszechniał, wzorem swego politycznego mistrza i poprzednika na praskim Hradzie Tomasza Garrigue’a Masaryka (1850-1937), założyciela państwa czechosłowackiego. Wśród polityków Havel był ewenementem także i z tego powodu, że jego oficjalne przemówienia i wystąpienia nie mają nic z urzędowej sztampy, a ich lektura może być naprawdę pasjonująca.

Václav Havel urodził się 5 października 1936 roku w Pradze w znanej i zamożnej rodzinie mieszczańskiej. Jego ojciec, również noszący imię Václav, był właścicielem dwóch wysokiej klasy restauracji, do niego także należały tereny na wzgórzu Barrandov, na którym stryj Miloš Havel wybudował świetnie prosperujące atelier filmowe. Václav Havel, razem z młodszym o dwa lata bratem Ivanem, większość dzieciństwa spędził w majątku Havlów położonym w lasach niedaleko morawskiego Tisznova, trzy godziny jazdy autem z Pragi. Bracia chodzili do pobliskiej szkoły powszechnej, ale mieli także własną guwernantkę. Václav Havel był dzieckiem nastawionym introwertycznie i refleksyjnie, wcześnie nauczył się czytać i już w wieku pięciu lat przeczytał Biblię. W rodzinie Havlów panowała atmosfera szacunku 
dla pierwszego prezydenta Czechosłowacji Tomasza Garrigue'a Masaryka i w takim otoczeniu Václav Havel od najmłodszych lat kształtował swą osobowość i myślenie o świecie. „Wyrosłem - przyznawał - w intelektualnej atmosferze Masarykowskiego humanizmu" (Simmons 1993: 42).

Po wojnie matka (Božena Havlová) chciała, aby rodzina wyemigrowała do Wielkiej Brytanii. Ojciec jednak po głębokim namyśle odrzucił ten pomysł. Wokół rodziny Havlów panował nieprzychylny klimat, gdyż w niektórych środowiskach - zwłaszcza wśród ciągle zyskujących na znaczeniu komunistów - stryja Miloša Havla oskarżano o kolaborację z Niemcami. W czasie wojny prowadził on wytwórnię filmową $\mathrm{AB}$ na Barrandovie. Wprawdzie nie powstał w niej żaden jawnie pronazistowski film, ale nakręcono tam - pod presją Niemców - niektóre sceny do propagandowego antysemickiego filmu Żyd Süss (Keane 1999: 38).

Po komunistycznym zamachu stanu z lutego 1948 roku sytuacja rodziny Havlów, której skonfiskowano wszystkie majątki, stała się szczególnie trudna. Na kilka miesięcy przed zamachem Václav Havel trafił do szkoły $\mathrm{z}$ internatem w Podiebradach. Już w tym czasie przejawiał szerokie zainteresowania humanistyczne, podejmował pierwsze próby literackie, pisząc poezje i baśnie, a także marzył o zawodzie reżysera filmowego. Jesienią 1952 roku, zachęcony przez matkę, 16-letni Havel z grupą przyjaciół utworzył nieformalną grupę artystyczno-literacką, która przyjęła nazwę „Trzydziestoszóstkowcy" (Šestatřicátníci), symbolizującą, że grupa skupiała ludzi urodzonych w 1936 roku. W jej ramach toczono dyskusje o sztuce, literaturze i polityce, wydawano samizdatowe czasopismo, organizowano nieformalne kongresy i sympozja. Havel, którego koledzy nazywali „Żuk” (Chrobák), był niekwestionowanym liderem grupy.

„Niewłaściwe” burżuazyjne pochodzenie zamknęło przed Havlem możliwość pójścia na wymarzone studia w zakresie teatrologii. Po odbyciu służby wojskowej zmuszony był podjąć pracę asystenta w laboratorium chemicznym. Zainteresował się wówczas chemią, prowadził własne doświadczenia i uczęszczał na zajęcia wieczorowej średniej szkoły chemicznej. Po jej ukończeniu usiłował dostać się na studia, jego podanie zostało jednak odrzucone. W końcu przyjęto go na wydział ekonomiczny politechniki w Pradze. Ten kierunek zupełnie go nie interesował, podejmował więc starania o przeniesienie się do szkoły teatralnej, jednak bez powodzenia. 
Po porzuceniu studiów podjął pracę dekoratora w teatrze, uważając, że da mu to sposobność przeniknięcia do życia teatralnego. Początkowo pracował w teatrze „ABC”, a później, od 1960 roku, w teatrze „Na Zábradlí”, w którym przez osiem lat był kolejno technikiem-dekoratorem, reżyserem i dramatopisarzem. Po latach Havel wspominał, że „niewłaściwe” pochodzenie w połączeniu z koniecznością życia w realiach komunistycznego kraju pozwoliło mu oglądać świat ,z dołu”, czyli widzieć go takim, jakim jest naprawdę, a wiedza ta potem pomogła mu ustrzec się przed różnymi iluzjami czy zmistyfikowanymi wyobrażeniami.

W 1956 roku Havel poznał starszą od siebie o blisko cztery lata Olgę Šplíchalovą. Ta znajomość przeobraziła się w miłość, co z początku bardzo nie odpowiadało matce Havla, która wybranki syna nie darzyła sympatią. Olga pochodziła bowiem z ubogiej rodziny robotniczej z Žižkova, imała się różnych zajęć - pracowała jako sprzedawczyni w sklepie, sekretarka w biurze i bileterka w teatrze. Od piętnastego roku życia wychowywała pięcioro dzieci swej starszej siostry. Olga nie miała wykształcenia, ale była energiczną kobietą o szerokich horyzontach. Ulubionym miejscem spotkań Václava i Olgi stała się słynna praska kawiarnia literacka Slavia. 9 lipca 1964 roku Václav Havel i Olga Šplíchalova zawarli związek małżeński.

Rok wcześniej w teatrze „Na Zábradlí” wystawiona została pierwsza sztuka Havla Garden party (Zahradní slavnost), która wywołała żywe reakcje i zapewniła autorowi międzynarodowy rozgłos. Opinię znakomitego dramatopisarza Havel potwierdził kolejną sztuką Powiadomienie (Vyrozuměni), która miała swą premierę w 1965 roku. Lata sześćdziesiąte były najbardziej płodnym okresem w jego twórczości, napisał wówczas ponad dziesięć dramatów i jednoaktówek. Stałym motywem jego twórczości dramatycznej było pokazywanie i ośmieszanie absurdów wytwarzanych przez zbiurokratyzowaną strukturę komunistycznego państwa. Pierwszą czytelniczką i recenzentką dramatów Havla zawsze była żona Olga, z której zdaniem bardzo się liczył. Poza dramatami pisywał także liczne artykuły, eseje i szkice, które ukazywały się głównie na łamach pism „Kvĕten” i „Tvář”, wydawanych przez związek pisarzy. W 1965 roku wszedł do rady wydawniczej tego drugiego pisma.

Havel był aktywnym uczestnikiem burzliwych wydarzeń Praskiej Wiosny 1968 roku. Stanął na czele powstałego w marcu tego roku Koła Pisarzy Niezależnych i działał w szeregach jednoznacznie antykomunistycznego 
Klubu Zaangażowanych Bezpartyjnych. Domagał się pełnego pluralizmu politycznego, a politykę reformatorskiej ekipy Aleksandra Dubczeka uważał za zbyt pasywną i kunktatorską. ,Według Havla - pisze jedna z jego biografek Eda Kriseová - rok sześćdziesiąty ósmy był schizofreniczny, dlatego że prawda nie była wypowiedziana" (Kriseová 1991: 54). W jego twórczości $\mathrm{z}$ tego okresu dominuje drobiazgowa analiza i obnażanie wszechobecnego w komunizmie mechanizmu hipokryzji i kłamstwa. Korzystając z politycznej odwilży, Václav i Olga Havlowie w 1968 roku udali się w kilkutygodniową podróż do Wielkiej Brytanii i Stanów Zjednoczonych, którą mogli odbyć dzięki zagranicznemu stypendium. Brutalne stłumienie Praskiej Wiosny w sierpniu 1968 roku przez inwazyjne wojska Układu Warszawskiego było dla Havla - podobnie jak dla ogromnej większości Czechów i Słowaków - traumatycznym doświadczeniem, przeżyciem z gatunku tych, które już na zawsze pozostają w świadomości i nie dają się z niej wyprzeć. To wydarzenie było dla niego równoznaczne z całkowitym bankructwem realnego socjalizmu i fiaskiem idei ,socjalizmu z ludzką twarzą".

W następnych latach Havel nie zmienił swoich poglądów, stał się więc pisarzem zakazanym, a jego twórczość znalazła się na indeksie. Prace czeskiego dramaturga i eseisty ukazywać się mogły albo w podziemiu, albo za granicą. Skoro nie chciał kłamać, a życie w prawdzie uczynił swoją dewizą, musiał zostać dysydentem. Sam mówił, że stał się nim, ponieważ pisał to, co myślał, a nie to, co inni myśleli, że powinien pisać. Uważał, że do bycia dysydentem skłania człowieka pragnienie życia w prawdzie oraz poczucie odpowiedzialności.

Do roli jednego z czołowych opozycjonistów wyniosła Havla głośna polemika - toczona na przełomie roku 1968 i 1969 - z pisarzem Milanem Kunderą (cf. Brdečková, Švehla, Třešňák 2011: 9). Podczas gdy Kundera wielbił Praską Wiosnę, twierdząc, że wprowadziła Czechów i Słowaków do „środka światowych dziejów”, Havel był daleki od idealizowania - skromnego jego zdaniem - dorobku Praskiej Wiosny, a stanowisko Kundery uznawał za ,prowincjonalny mesjanizm”. Po stłumieniu Praskiej Wiosny Kundera doszedł natomiast do przekonania, że nadszedł czas, aby wrócić do tzw. czeskiego pragmatyzmu i zaadaptować się do zaistniałej sytuacji, która wcale nie jest taka zła. Havel z kolei wzywał wówczas do obudzenia czeskiego ducha narodowego oraz piętnował narastające tendencje kapitulanckie i nieumiejętność zdobycia się na heroizm w czasach wielkiej próby. 
Argumentował, że szanujące się narody zawsze muszą być twórcami własnego losu i nie mogą zezwolić na to, aby sprowadzono je do roli pasywnego obiektu, którym manipulują inni.

Lata siedemdziesiąte XX wieku były dla Václava Havla właśnie takim okresem heroicznym. Niemal samotnie działający dysydent rzucił wyzwanie potężnej machinie totalitarnego państwa. W 1975 roku Havel w podziemiu opublikował polityczny esej List otwarty do Sekretarza Generalnego $K P C z$ Gustava Husáka, pisał w nim, że Czechosłowacja jest krajem apartheidu, w którym żyją dwie z natury obce sobie i wrogie klasy - wszechwładna kasta rządząca i poddane represjom społeczeństwo (Havel 2011: 56-86). W grudniu 1976 roku w mieszkaniu Havla odbyło się zebranie grupy dysydentów, podczas którego zapadła decyzja o powołaniu do życia otwartego ruchu obywatelskiego działającego w obronie praw człowieka. Powstanie Karty 77 - bo taka nazwę przyjęła inicjatywa - oficjalnie ogłoszono 1 stycznia 1977 roku, a Havel został jednym z trzech pierwszych jej rzeczników. Karta 77 odwoływała się do wzorów polskiej opozycji demokratycznej, a w szczególności Komitetu Obrony Robotników (KOR). Havla z założycielami KOR-u, a zwłaszcza z Adamem Michnikiem, potem przez lata łączyły więzy głębokiej przyjaźni. Czescy i polscy dysydenci wielokrotnie spotykali się nielegalnie na czesko-polskiej granicy w Karkonoszach. W kwietniu 1978 roku Havel znalazł się w gronie inicjatorów kolejnego dysydenckiego przedsięwzięcia, a mianowicie broniącego więźniów politycznych Komitetu Obrony Niesprawiedliwie Prześladowanych (VONS).

W tym samym roku Havel ogłosił słynny esej Siła bezsilnych (Moc bezmocných). Chciał w nim nakreślić przyczyny powstania Karty 77, ale ostatecznie tekst zawierał głębsze rozważania o naturze systemu komunistycznego. Autor wskazywał na konieczność przeciwstawienia komunizmowi ludzkiej godności, jest w nim bowiem stale poniżana, a rządzącym chodzi o to, aby zupełnie zanikła. Następnie obnażał samą istotę systemu komunistycznego, którą - w jego przekonaniu - było zmuszanie ludzi do aprobowania jego mechanizmów poprzez uczestniczenie w zbiorowym kłamstwie polegającym na udawaniu, że istnieją rzeczy nieistniejące przy jednoczesnym wypieraniu ze świadomości faktów. Tej mistyfikacji przeciwstawiał wyniesiony do rangi wielkiego postulatu ideał życia w prawdzie, a jego upowszechnienie - utrzymywał - okaże się dla ustroju zabójcze (Havel 2011: 87-158). 
Tego rodzaju analizy oraz intensywna dysydencka działalność sprawiły, że Havel stał się wrogiem numer jeden komunistycznego reżimu. Organ partii komunistycznej „Rudé právo” bezlitośnie go zwalczał jako „człowieka pochodzącego z milionerskiej rodziny” oraz „zatwardziałego antysocjalistę i kontrrewolucjonistę". Havel był wielokrotnie więziony i to pod najbłahszymi zarzutami - w sumie przesiedział prawie pięć lat. Po raz pierwszy „za działalność wywrotową” został aresztowany 14 stycznia 1977 roku, najsurowszy zaś wyrok otrzymał w procesie pokazowym urządzonym w październiku 1979 roku, kiedy to za „działalność antypaństwową” skazano go na karę czterech i pół roku pozbawienia wolności. Karę tę odbył niemal w całości, z więzienia wypuszczono go dopiero w 1983 roku z uwagi na bardzo zły stan zdrowia. Władze obawiały się, że może umrzeć w więzieniu na zapalenie płuc, a to mogło wywołać groźne dla nich reperkusje na arenie międzynarodowej. $Z$ więziennej korespondencji do żony powstał zbiór Listy do Olgi (Dopisy Olze). Wbrew tytułowi, nie jest to jednak rzecz o uczuciach, lecz pozycja zawierająca przemyślenia o charakterze filozoficznym i metafizycznym (Havel 1993a). W latach osiemdziesiątych Havel wielokrotnie był szykanowany i prześladowany przez policję polityczną StB, która śledziła niemal każdy jego ruch.

Havel, pomimo aktywności dysydenckiej i represji, jakim został poddany, nie zaniedbywał twórczości dramatopisarskiej. W latach siedemdziesiątych i osiemdziesiątych spod jego pióra wyszło kilka dramatów, a najbardziej znane z nich to: Górski hotel (Horský hotel), Audiencja (Audience), Wernisaż (Vernisáž), Kuszenie (Pokoušení), Rewaloryzacja (Asanace) i Largo desolato. Były one z wielkim powodzeniem wystawiane w wielu zagranicznych teatrach. Zarówno twórczość Havla, jak i działalność w obronie praw człowieka zostały docenione za granicą. Otrzymał wiele prestiżowych nagród, m.in. w 1981 roku francuską nagrodę Prix Plaisir du Theatre, w 1986 roku holenderską nagrodę Erazma z Rotterdamu, a w 1989 roku Nagrodę Pokojową niemieckich wydawców i szwedzką Nagrodę im. Olofa Palmego.

Ostatni raz Havel został aresztowany w styczniu 1989 roku, skazano go wtedy na 9 miesięcy więzienia za ,nawoływanie do demonstracji ulicznych". Proces ten spotkał się z ostrą krytyką międzynarodowej opinii publicznej, dzięki której został warunkowo zwolniony 17 maja 1989 roku. Służba bezpieczeństwa zatrzymała go jeszcze na krótko w październiku 1989 roku. 
W listopadzie tego roku Havel błyskawicznie awansował do rangi bohatera narodowego, a jego nazwisko głośno skandowali demonstrujący na ulicach Pragi uczestnicy aksamitnej rewolucji (w jej wyniku ostatecznie obalono w Czechosłowacji system komunistyczny). Już 19 listopada 1989 roku spontanicznie powstało Forum Obywatelskie (Občanské fórum - OF), demokratyczny ruch społeczny, w którym czołową rolę odgrywali dawni dysydenci z Karty 77, a Havel od razu stał się jego nieformalnym liderem. 10 grudnia OF ogłosiło go kandydatem na prezydenta demokratycznej Czechosłowacji, a 29 grudnia 1989 roku Václav Havel - symbolizujący opozycję demokratyczną jak nikt inny - przez komunistyczny jeszcze parlament został jednomyślnie wybrany na prezydenta Czechosłowacji. Kiedyś napisał, że „polityka w tym kraju jest teatrem absurdu”. Rzeczywiście, dramaturg Havel trafił w istotę rzeczy - jeszcze kilka miesięcy wcześniej przebywał w więzieniu jako ,wróg państwa”.

W prezydenckim orędziu noworocznym wygłoszonym 1 stycznia 1990 roku Havel odwoływał się do Tomasza Garrigue'a Masaryka i jego idei polityki opartej na moralności. Mówił, że tak właśnie rozumie swą działalność. Wzywał, żeby w nowych czasach, które rozpoczęły się po upadku komunizmu, przywrócić rządzeniu głęboki moralny sens i uczynić wszystko, aby polityka przestała być sztuką spekulacji, intryg czy pragmatycznych manewrów, a stała się jedną z dróg urzeczywistniania powszechnego szczęścia. W tych słowach zawarty był prezydencki program polityczny w miniaturze, któremu potem - trzeba to wyraźnie podkreślić - Havel starał się dochować wierności.

5 lipca 1990 roku wyłoniony już w wolnych wyborach parlament ponownie wybrał Havla na prezydenta. Tym razem jednak nie było już jednomyślności, bo 50 posłów opowiedziało się przeciwko niemu. Taki wynik głosowania Havel uznał za świadectwo tego, że w kraju zapanowała już autentyczna demokracja i w charakterystyczny dla siebie, nieco przewrotny sposób, stwierdził, porównując się do długoletniego komunistycznego prezydenta Gustava Husáka: „Nie czułbym się dobrze, gdybym był wybierany jednomyślnie, jak mój poprzednik" (Pehe 1990: 8).

Tymczasem w ekspresowym tempie pogłębiać się zaczęły rozbieżności między Czechami i Słowacją: polityczne, gospodarcze i wszelkie inne. Sprawując urząd głowy państwa, Havel dążył do utrzymania jedności kraju, którą coraz bardziej zdecydowanie kwestionowały zyskujące na znaczeniu 
nacjonalistyczne ugrupowania słowackie. Był przekonany, że interes narodowy Słowaków może być zaspokojony w ramach dobrze zorganizowanej Czechosłowacji. Na tym polu poniósł jednak dotkliwą porażkę polityczną. Koegzystencja Czechów i Słowaków w ramach jednego państwa okazała się niemożliwa. W obliczu postępującego rozpadu państwa i braku konstytucyjnych uprawnień do powstrzymania tego procesu, a także ze względu na odmowę poparcia jego kandydatury na kolejną kadencję prezydencką przez większość ugrupowań słowackich w parlamencie federalnym, Havel 20 lipca 1992 roku po 935 dniach sprawowania urzędu złożył dymisję. Do końca istnienia Czechosłowacji nie udało się wyłonić prezydenta.

Po rozpadzie i powstaniu 1 stycznia 1993 roku niezależnych Czech i Słowacji, Václav Havel stał się w naturalny sposób pierwszoplanowym kandydatem na stanowisko głowy państwa czeskiego. 26 stycznia 1993 roku parlament czeski wybrał go na pierwszego prezydenta Republiki Czeskiej. Havel ustanowił przy okazji pewien polityczny rekord, stał się mianowicie pierwszym na świecie politykiem będącym prezydentem dwóch różnych państw - Czechosłowacji i Czech. 20 stycznia 1998 roku został wybrany na drugą i zarazem - z przyczyn konstytucyjnych - ostatnią 5-letnią kadencję, która wygasła 2 lutego 2003 roku.

Najwyższy urząd w państwie Havel sprawował, unikając angażowania się w bieżące rozgrywki polityczne i starając się odgrywać rolę ponadpartyjnego autorytetu moralnego i arbitra politycznego, którego zadanie charakteryzował w następujących słowach: ,Trzeba, bym się raczej koncentrował na kwestiach systemowych, dotyczących ogólnych wartości - czyli na tym, co w ten czy inny sposób związane jest z podstawowymi problemami istnienia państwa, jego demokratyczną tożsamością i stabilnością polityczną" (Havel 1993b). Często krytykował czeskie partie polityczne, którym zarzucał myślenie kategoriami partykularnego interesu i traktowanie państwa jako areny zmagań o stanowiska i wpływy. Stąd też stosunki Prezydenta z kolejnymi rządami nie układały się dobrze. Niezmiennie jednak Havel cieszył się bardzo wysokim zaufaniem społecznym, a większość obywateli w pełni akceptowała jego działania i realizowany model prezydentury. Havel, który w wyniku reprywatyzacji odzyskał znaczną część majątku rodzinnego, co uczyniło zeń człowieka bardzo zamożnego, wraz z żoną Olgą udzielał się w rozmaitych akcjach charytatywnych, nie szczędząc na te cele środków z prywatnych aktywów. Tego rodzaju aktywność i autentyczna wrażliwość 
społeczna, której często dawał przykłady, dodatkowo ugruntowywała i tak duży autorytet Prezydenta. Sporą aktywność przejawiał Havel w polityce międzynarodowej, jego głos był zawsze dobrze słyszalny w przypadkach wszystkich poważniejszych kryzysów czy konfliktów, gdy domagał się od społeczności międzynarodowej stanowczej reakcji w obronie prześladowanych i skrzywdzonych.

27 stycznia 1996 roku w wieku 62 lat zmarła powszechnie ceniona i uwielbiana żona prezydenta Olga Havlová. Gdy po roku (4 stycznia 1997 roku) Prezydent ponownie się ożenił, jego wybranką była 43-letnia wówczas aktorka Dagmar Veškrnová, duża część czeskiej opinii publicznej przeżyła spory szok. Wprawdzie Havel publicznie tłumaczył motywy tego kroku i prosił rodaków o jego zrozumienie, to jednak wielu Czechów uznało powtórny ożenek za niestosowny. W konsekwencji społeczne zaufanie do Havla spadło wtedy o około 20 procent i do końca prezydentury nie udało się już odbudować wysokich notowań.

Po zakończeniu kadencji prezydenckiej Havel był nadal aktywny w życiu publicznym. Na ogół krytycznie wypowiadał się o kondycji czeskiej polityki. Pewne nadzieje wiązał z Partią Zielonych, którą oficjalnie popierał, jednak mimo to nie odniosła ona sukcesu politycznego. Udzielał się na arenie międzynarodowej, uczestnicząc w inicjatywach broniących praw człowieka i swobód politycznych w systemach niedemokratycznych. Założył, gromadzącą materiały dokumentujące jego działalność polityczną, Bibliotekę Havla, uznając amerykańską tradycję tworzenia tego typu instytucji przez byłych prezydentów za ze wszech miar godną naśladowania w Czechach. W 2005 roku publiczna telewizja czeska przez kilka miesięcy realizowała program wybierania „Najwybitniejszego Czecha wszech czasów”. W tym konkursie Havel zajął trzecie miejsce, ustępując jedynie królowi Karolowi IV (1346-1378), budowniczemu Mostu Karola i założycielowi Uniwersytetu Karola oraz Tomaszowi G. Masarykowi. Po niemal dwudziestoletniej przerwie napisał dramat Odejścia (Odcházení), który ukazał się drukiem w listopadzie 2007 roku, a w marcu 2008 roku został wystawiony w praskim Teatrze na Vinohradach. Tematem sztuki uczynił rozterki człowieka, który po latach uprawiania polityki szuka dla siebie nowego miejsca w życiu, co okazuje się nadzwyczaj trudne. Wielu uważało, że Havel pisał o sobie i własnych doświadczeniach. Na podstawie tej sztuki sam wyreżyserował film fabularny, który trafił do czeskich kin w marcu 2011 roku. 
Od końca 1996 roku Havel nieprzerwanie miał poważne kłopoty ze zdrowiem. Przeszedł wiele skomplikowanych operacji (m.in. operację wycięcia fragmentu prawego płuca ze względu na rozwijający się nowotwór i operację jelita grubego). Śmierć dosięgła go 18 grudnia 2011 roku w jego wiejskim domu w Hrádečku (Vlčice).

\section{$* * *$}

Po zarysowaniu drogi życiowej i sylwetki politycznej Václava Havla przejdźmy do scharakteryzowania jego poglądów i intelektualnych poszukiwań. Jedną z najważniejszych ról ideowych Havla była rola poszukiwacza absolutu. Szukał go zresztą raczej nie jako profesjonalny filozof, lecz jako polityk zainspirowany filozofią. Nie przypisywał rządzeniu wartości absolutnej, ale traktował je jako jedną z dróg umożliwiających poznanie prawdy o człowieku. Havel był działaczem niestandardowym, dla którego polityka stanowiła dziedzinę stanowczo zbyt wąską, co manifestował i podkreślał na każdym niemal kroku. Krępowała i wiązała zarówno jego osobowość, jak i wyobraźnię, ponieważ jej sztywne reguły i zinstytucjonalizowana natura tworzyły dlań dość uciążliwy gorset. $Z$ tej przyczyny Havel nieustannie usiłował ją może nie tyle przezwyciężyć, ile nadać szerszą skalę - refleksji i filozofii. W jego przekonaniu polityk, człowiek z założenia aktywny i dynamiczny, który decyduje o losach ludzi i narodów, jest szczególnie predestynowany - bo ma znakomitą perspektywę patrzenia - do poznawania mechanizmów rządzących światem i ludzką naturą. Niestety - ubolewał - osoby o takim właśnie zacięciu należą wśród polityków do rzadkości. W rezultacie polityka, pozbawiona wymiaru duchowego i szerszego horyzontu poszukiwań, staje się mniej lub bardziej prymitywną i bezwzględną grą o władzę. Dlatego też czeski Prezydent był tak stanowczym admiratorem koncepcji zakładającej szerokie uczestnictwo intelektualistów w życiu publicznym. Wcale przy tym nie uważał, że natura polityka i intelektualisty wzajemnie się wykluczają. W jego pojęciu były one doskonale komplementarne, pod warunkiem wszakże, iż intelektualista z jednej strony będzie umiał łączyć skłonność do refleksji z odpowiedzialnością i zdolnością do podejmowania decyzji, z drugiej zaś - nie będzie „uparcie podążać za swoją ideą” i nie zlekceważy „wszystkich możliwych zależności, interesów, poglądów innych" (Bankowicz 1995: 4).

Václav Havel stał się gorącym orędownikiem zagadkowej idei niepolitycznej polityki. Z pewnością niewielu rzeczy życzył sobie tak bardzo jak 
tego, by polityka stała się apolityczna. Sama jednak idea nie pochodziła od niego, a od Tomasza Garrigue'a Masaryka. Havel był wyraźnie zafascynowany osobą tego legendarnego prezydenta-filozofa i to już od wczesnej młodości. Uważał się za spadkobiercę stylu uprawiania polityki Masaryka i strażnika jego politycznego dziedzictwa. Tak jak on pragnął pełnić funkcję duchowego przywódcy narodu, nie zaś wpływowego lidera politycznego. Po Masarykowsku sprawował też prezydenturę, widząc w niej nie tylko urząd polityczny, ale przede wszystkim środek moralnego oddziaływania na społeczeństwo. Starał się więc wzorem swego wielkiego poprzednika na praskim Hradzie traktować politykę jako służbę dla społeczeństwa i przeciwstawiał ją zarówno - jak to nazywał - ,technologii konkurencji o władzę”, jak i „politycznemu makiawelizmowi”, który wspiera się na zasadzie, że cel uświęca środki. Havel zawsze potępiał polityków ceniących sobie tylko władzę i skuteczność. Widzenie zaś wyłącznie celów gospodarczych czy finansowych przy jednoczesnym gubieniu wątku ludzkiego i moralności traktował jako powrót do marksistowskiej formuły o bazie i nadbudowie, a za szczególny paradoks uważał to, że w Europie Środkowej bezwzględnymi piewcami wyższości ekonomii nad wszystkimi innymi dziedzinami życia stali się liberalni reformatorzy.

Tomasz G. Masaryk pisał, że ,polityka władzy, która obywa się bez moralności, to zoologia" (Masaryk 1924: 33-34). Tak samo sprawę tę widział Havel, według którego między moralnością i polityką istnieje nierozerwalny związek, a najważniejszą wartością polityczną nie jest władza, lecz dobro człowieka i wierność prawdzie.

Jedno - mówił czeski Prezydent - jest pewne: moralność i niemoralność mają bezpośrednie konsekwencje polityczne, a z kolei decyzje polityczne mają skutki moralne. Dlatego uważam, że jest bzdurą oddzielanie moralności od polityki i twierdzenie, że są to dwie różne dziedziny, całkiem ze sobą nie związane. Mówienie czegoś takiego czy wręcz praktykowanie tego jest - paradoksalnie - nie tylko głęboko niemoralne, ale jednocześnie błędne politycznie. Moralność jest po prostu wszechobecna, podobnie jak polityka. A polityka, która oddzieli się od moralności, jest po prostu i tylko złą polityką (Havel 1995: 20).

Polityka przy tym nie powinna wypływać z takiej bądź innej doktryny, ale zawsze z serca i autentycznych potrzeb. Słowem, polityka to zastosowana w praktyce etyka. W życiu publicznym Havel, odwołując się do 
Masarykowskiej tradycji, zawsze na pierwszym miejscu stawiał więc etykę i był zwolennikiem społeczeństwa obywatelskiego, które powinno kierować się moralnością, ponieważ bez moralności istnienie systemu demokratycznego jest niemożliwe. Demokracja nie może właściwie funkcjonować, gdy traktuje się ją wyłącznie jako zestaw instytucji i procedur. Wymaga ona bowiem również głęboko zakorzenionego w moralności systemu wartości i odpowiedniej kultury politycznej. Bez tego demokracja obumiera, stając się fikcją.

Havel traktował tradycyjną politykę z wyraźną dozą podejrzliwości. Ten dystans nie jest rzecz jasna równoznaczny z anarchistyczną tęsknotą do świata pozapolitycznego i pozapaństwowego, w którym nie występuje zjawisko władzy. Do tego Havel nie zmierzał i od tego był jak najdalszy. W niepolitycznej polityce nie chodzi przecież o zniesienie władzy, ale o doprowadzenie do stanu, w którym polityka nie byłaby tak bez reszty i do końca zdeterminowana przez władzę i dążenie do jej sprawowania lub zdobycia. Powołaniem prawidłowej i głęboko słusznej polityki - właśnie polityki niepolitycznej - powinno być sprawowanie władzy nie dla samej władzy, ale po to, żeby za pośrednictwem tego środka rozwiązywać istniejące problemy i budować lepsze społeczeństwo. W tym sensie niepolityczna polityka stanowi zaprzeczenie polityki politycznej, czyli polityki władzy, choć nie jest negacją polityki jako takiej.

Współcześnie polityka władzy z reguły przyjmuje postać polityki partyjnej. $Z$ tego powodu Havel nie darzył sympatią partii politycznych i spoglądał na nie z nieufnością. Oczywiście zdawał sobie sprawę z faktu, że partie są podstawowym elementem systemu demokratycznego i że bez ich rywalizacji nie byłoby demokracji. Jednakowoż przerażała go rzeczywistość państwa całkowicie upartyjnionego, w którym partie zawłaszczają jego struktury i instytucje bez reszty i traktują je jako sferę swych wyłącznych wpływów. Jest to zjawisko, które niestety często obserwujemy.

Występuję - mówił - stale przeciwko partiokracji. Uważam, że partie polityczne mają być instrumentem, a nie istotą i celem. Są instrumentem służącym do obsadzania przewidzianych przez prawo instytucji, które mają reprezentować społeczeństwo. Nie są wszakże rzeczywistym nosicielem władzy. Tę rolę spełniać może jedynie władza ustawodawcza i wykonawcza, po prostu państwo. Nie podoba mi się, gdy czasami odnieść można wrażenie, że to właśnie państwo należy do partii politycznych. W najgorszym przypadku państwo staje się własnością niewybieralnych sekretariatów partyjnych, które decydują 
o sprawach państwowych. Tego przecież doświadczyliśmy za komunizmu w ekstremalnej postaci (Bankowicz 1995: 4).

Skrajne uwielbienie dla partii i partyjności wiedzie więc do totalitaryzmu, aczkolwiek skrajna wrogość wobec nich prowadzi do dyktatury. Havel życzył sobie, aby współczesne partie przestały spełniać funkcję - jak to nazywał - „wind do władzy” i by z większą uwagą poświęciły się pracy ideowej.

W Havlowskiej, i swoją drogą także Masarykowskiej, niepolitycznej polityce wielu badaczy widzi postulat w najlepszym razie romantyczny, jeśli nie wręcz utopijny. Jest to bowiem koncepcja intelektualnie atrakcyjna, ale chyba zupełnie pozbawiona waloru praktyczności, bo polityka, jaką znamy, jest zawsze polityką polityczną. Na pewno jest to idea z dużą dozą wyobraźni, niestandardowa i wielce oryginalna. We współczesnym świecie coraz bardziej zagrożonym partiokracją i bezdusznym stylem politycznego przywództwa idea ta $\mathrm{z}$ całą pewnością zasługuje na uwagę i refleksję. Może właśnie w niej należy szukać remedium na niedostatki dzisiejszej demokracji. Niemniej jednak stałe poszukiwanie przez Havla całościowej wizji politycznej i jego nawoływanie o duchowość życia publicznego narażały go na zarzut, skądinąd trudny do odparcia, że zamierzał odgrywać rolę swoistego inżyniera społecznego, a przełożenie jego moralizatorskich zapędów na praktykę polityczną groziłoby urzeczywistnieniem systemu z urzędową ideologią, słowem - czegoś na wzór „,nowego wspaniałego świata” w duchu Huxlejowskim. Tu być może tkwiła przyczyna tego, że olbrzymi szacunek dla Havla i aprobata dla jego poczynań jako prezydenta nie szły w Republice Czeskiej w parze z respektowaniem jego politycznych sugestii, by nie powiedzieć wskazań. W efekcie inicjatywy polityczne najbliższe Prezydentowi i podejmujące ideę niepolitycznej polityki nigdy nie cieszyły się społecznym uznaniem. Niepolityczna polityka okazywała się niezwykle trudna do realizacji.

\section{$* * *$}

Václav Havel był intelektualistą, który porzucił świat intelektualnej finezji i życiowego komfortu, by zanurzyć się w kierujący się bezwzględnymi - a niekiedy wręcz brutalnymi - regułami świat polityki. Stał się politykiem, aby wypełnić swoją obywatelską powinność wobec kraju, którego 
był synem. Walczył z totalitaryzmem w imię wolności i demokracji, a kiedy udało się cele te osiągnąć, siłą wydarzeń wyniesiony został do sprawowania najwyższej państwowej godności - urzędu prezydenta republiki. Przeszedł zatem osobliwą drogę od dysydenta do prezydenta. Jako głowa państwa uprawiał politykę z intelektualnym namysłem i z krytycznym oglądem życia publicznego. Był politykiem, dla którego polityka i władza z całą pewnością nie stały się esencją życia. W ten sposób urzeczywistnił jedyny w swoim rodzaju ideał niepolitycznego polityka i nieprezydenckiego prezydenta. Całkowicie zasłużenie przeszedł do historii jako jeden z największych politycznych, intelektualnych i moralnych autorytetów współczesnego świata.

\section{Literatura}

Bankowicz M., 1995, Prezydent wszystkich Czechów. Václav Havel, „Tygodnik Powszechny" nr 46, s. 1, 4.

Brdečková T., Švehla M., Třešňák P., 2011, Nečekat, co udělaji oni, „Respekt” nr 40, Mimořádné Vydání, s. 9.

Havel V., 1993a, Listy do Olgi (czerwiec 1979 - wrzesień 1982). Wybór, wyb. J. Baluch, przeł. M. Szczepańska, Warszawa.

Havel V., 1993b, Trzy lata - dzieje dramatu, przeł. A.S. Jagodziński, „Gazeta Wyborcza" nr 53, 4 marca, s. 10.

Havel V., 1995, Czeski kompleks, przeł. A.S. Jagodziński, „Gazeta Wyborcza” nr 139, 17-18 czerwca, s. 20.

Havel V., 2011, Siła bezsilnych i inne eseje, przeł. A.S. Jagodziński, Warszawa.

Keane J., 1999, Václav Havel. Politická tragédie v šesti dĕjstvích, Praha.

Kriseová E., 1991, Václav Havel - životopis, Brno.

Masaryk T.G., 1924, Les Problèmes de la Démocratie, Paris.

Pehe J., 1990, The New Federal Assembly: The Balance Sheet after One Month, „Report on Eastern Europe", 17 August, s. 7-11.

Simmons M., 1993, Nesmělý prezident. Životopis Václava Havla, Praha. 
